\title{
MORPHOLOGICAL STUDY OF THE STYLOID PROCESS OF TEMPORAL BONE IN THE POPULATION OF NORTH-EAST INDIA
}

\author{
Bijoy Kumar Borah'1, Rubi Saikia², Jyotsna Bhuyan ${ }^{3}$ \\ ${ }^{1}$ Assistant Professor, Department of Anatomy, AMC, Dibrugarh, Assam. \\ ${ }^{2}$ Associate Professor, Department of Anatomy, JMC, Jorhat, Assam. \\ ${ }^{3}$ Demonstrator, Department of Anatomy, AMC, Dibrugarh, Assam.
}

\begin{abstract}
\section{BACKGROUND}

The styloid process is a slender, pointed bony projection that extends downward and forward from the inferior surface of the petrous part of the temporal bone, anterior to the stylomastoid foramen. The normal length of the styloid process ranges from $20-$ $30 \mathrm{~mm}$. It is said to be elongated if it measures $>30 \mathrm{~mm}$. An elongated styloid process could compress the important structures in its vicinity and give rise to a number of clinical symptoms described as the Eagle's syndrome. Severe cases of Eagle's syndrome call for surgical excision of the styloid process.

Aim- The present study is aimed to find out the incidence of elongated styloid process in the population of North-East India, as stylalgia can be a disturbing complaint.
\end{abstract}

\section{MATERIALS AND METHODS}

The study was carried out on 140 dry human skulls with intact styloid processes, procured from the Department of Anatomy, Department of Forensic Sciences, Institute of Pharmacy at Assam Medical College and from the Department of Anatomy at Jorhat Medical College, Assam. The selected skulls were examined macroscopically and all the styloid processes were measured for length. The skulls with elongated styloid process were photographed.

\section{RESULTS}

Out of the 140 dry skulls, 17 (12.1\%) presented with elongated styloid processes. Of these, $13(9.2 \%)$ skulls had unilateral elongation (4 right and 9 left sided) and 4 (2.8\%) skulls had bilateral elongation of the styloid process.

\section{CONCLUSION}

Elongated styloid process continues to be an enigma for the clinician, as it is implicated in the persistence of disturbing throat discomfort and pain. So it is important for the clinicians to be aware of incidence of elongated styloid process in various population to come to a proper diagnosis. In this study, the incidence of elongated styloid process was $12.1 \%$.

\section{KEYWORDS}

Skull, Styloid Process, Temporal Bone, Elongated Styloid Process, Eagle's Syndrome, Stylalgia.

HOW TO CITE THIS ARTICLE: Borah BK, Saikia R, Bhuyan J. Morphological study of the styloid process of temporal bone in the population of North-East India. J. Evolution Med. Dent. Sci. 2017;6(27):2213-2216, DOI: 10.14260/Jemds/2017/478

\section{BACKGROUND}

Derived from the Greek word 'Stylos' meaning 'the pillar,' the styloid process is a slender bony structure that extends downward and forward from the inferior surface of the petrous part of the temporal bone anterior to the stylomastoid foramen. Its base is cylindrical in shape and it gradually tapers towards the apex. In the living, the apex of the styloid process is located next to the tonsillar fossa at the lateral wall of the pharynx, between the internal and external carotid arteries. The styloid process gives origin to stylohyoid, styloglossus and stylopharyngeus muscles and attachment to the stylohyoid and stylomandibular ligaments. $(1,2)$ The styloid process is a derivative of the Reichert cartilage of the $2^{\text {nd }}$ branchial arch and along with the

Financial or Other, Competing Interest: None.

Submission 03-01-2016, Peer Review 18-03-2017,

Acceptance 24-03-2017, Published 01-04-2017.

Corresponding Author:

Dr. Rubi Saikia,

Associate Professor,

Department of Anatomy,

Jorhat Medical College, Assam.

E-mail: drrubisaikia@gmail.com

DOI: $10.14260 /$ jemds $/ 2017 / 478$ stylohyoid ligament and the lesser horn of the hyoid bone, it forms the stylohyoid complex.(3) Important structures seen surrounding the styloid process laterally are the facial nerve, the hypoglossal nerve, the occipital artery and the posterior belly of digastric muscle. Medially it is related to the lingual artery, the facial artery, superficial temporal artery, the maxillary artery, the internal carotid artery, the internal jugular vein and the stylomandibular ligament.

The normal length of the styloid process ranges from 25 $30 \mathrm{~mm}$. It is considered to be elongated when it is longer than $30 \mathrm{~mm}$. Various studies carried out worldwide suggest that elongated styloid process is seen in adults with frequency ranging from 2 - 30\%.(4) An elongated styloid process accompanied by calcification of the stylohyoid ligament can compress the structures in the vicinity triggering a series of symptoms like foreign body sensation in the throat, pain when moving the head, vertigo, dysphagia, otalgia, facial pain, headache, tinnitus and trismus. This set of symptoms associated with elongated styloid process is called the Eagle's syndrome. $(5,6,7,8)$ This study is aimed to identify the prevalence of elongated styloid process in the population of North-East India as regards to its location (unilateral or bilateral) as well as to measure the inter-styloid distance at various points. 


\section{MATERIALS AND METHODS}

Initially, we collected a total of 153 dry human skulls from the Department of Anatomy, Department of Forensic Science, Institute of Pharmacy at Assam Medical College and the Department of Anatomy at Jorhat Medical College, Assam. But after gross examination of the specimens, 13 skulls had to be discarded from the study as 9 of them had partially broken styloid process and 4 had completely broken (broken at the root) styloid process.

Thus, on the basis of intactness of the styloid process, 140 skulls were taken up for the present study.

\section{Inclusion and Exclusion Criteria}

Fractured skulls and skulls with partially or completely damaged styloid process were discarded from the present study.

After performing macroscopic examination of the skulls, the length of the styloid process was measured with the help of a vernier caliper. Measurements were taken from the base to the tip. Next, the interstyloid distance between the right and the left styloid process was measured at three points- at the base, at midpoint and at the tip. Data collected were recorded and tabulated. Those skulls with elongated styloid processes were photographed.

\section{RESULTS}

Among the 140 specimens, 17 (12.1\%) skulls presented with elongated styloid process. Of these, 13 (9.2\%) skulls had unilateral elongation ( 4 on the right side and 9 on the left side) and $4(2.8 \%)$ skulls had bilateral elongation of the styloid process.

\begin{tabular}{|c|c|c|}
\hline Specimen No. & $\begin{array}{c}\text { Length on } \\
\text { Right Side (mm) }\end{array}$ & $\begin{array}{c}\text { Length on } \\
\text { Left Side (mm) }\end{array}$ \\
\hline 1 & 31 & 32 \\
\hline 2 & 33 & 31 \\
\hline 3 & 38 & 40 \\
\hline 4 & 32 & 33 \\
\hline \multicolumn{3}{|c|}{ Table 1. Measurements of Bilaterally Elongated Styloid } \\
Process ( $\mathbf{n = 4}$
\end{tabular}

\begin{tabular}{|c|c|c|c|}
\hline Mean & Median & Range & $\begin{array}{c}\text { Interquartile } \\
\text { Range (IQR) }\end{array}$ \\
\hline 33.75 & 32.5 & 9 & 4 \\
\hline Table 2. Analysis of the Bilaterally Elongated Styloid \\
Process \\
\hline
\end{tabular}

\begin{tabular}{|c|c|c|}
\hline Specimen No. & Right Side (mm) & Left Side (mm) \\
\hline 1 & 32 & 29 \\
\hline 2 & 29 & 36 \\
\hline 3 & 27 & 31 \\
\hline 4 & 26 & 32 \\
\hline 5 & 34 & 28 \\
\hline 6 & 26 & 34 \\
\hline 7 & 28 & 33 \\
\hline 8 & 31 & 26 \\
\hline 9 & 27 & 34 \\
\hline 10 & 23 & 35 \\
\hline 11 & 33 & 27 \\
\hline 12 & 25 & 31 \\
\hline 13 & 28 & 34 \\
\hline \multicolumn{3}{|c|}{ Table 3. Measurements of Unilaterally Elongated Styloid } \\
\hline \multicolumn{3}{|c|}{} \\
\hline
\end{tabular}

Among the 13 skulls with unilaterally elongated styloid process, the longest one measured $36 \mathrm{~mm}$ (left side) and the shortest one measured $31 \mathrm{~mm}$ in three skulls (one right sided and two left sided).

\begin{tabular}{|c|c|c|c|}
\hline Mean & Median & Range & $\begin{array}{c}\text { Interquartile } \\
\text { Range (IQR) }\end{array}$ \\
\hline 29.96 & 30 & 13 & 6 \\
\hline Table 4. Analysis of the Unilaterally Elongated Styloid \\
Process \\
\hline
\end{tabular}

\begin{tabular}{|c|c|c|c|}
\hline $\begin{array}{c}\text { Specimen } \\
\text { No. }\end{array}$ & $\begin{array}{c}\text { Distance at } \\
\text { Base (mm) }\end{array}$ & $\begin{array}{c}\text { Distance at } \\
\text { Midpoint (mm) }\end{array}$ & $\begin{array}{c}\text { Distance at } \\
\text { the Tip }\end{array}$ \\
\hline 1 & 61 & 56 & 52 \\
\hline 2 & 63 & 58 & 54 \\
\hline 3 & 71 & 66 & 62 \\
\hline 4 & 64 & 58 & 54 \\
\hline Table 5. Showing the Interstyloid Distance of Bilaterally \\
Elongated Styloid Process (n=4) \\
\hline
\end{tabular}

It is seen that the interstyloid distance gradually decreases towards the tip of the styloid process. This means that bilaterally elongated styloid process could be a cause of compression of the midline structures of the neck, as they narrowed down the interstyloid space. In the present study, the narrowest interstyloid distance at the tip was found to be $52 \mathrm{~mm}$.

\begin{tabular}{|c|c|c|c|c|}
\hline $\begin{array}{c}\text { Level of } \\
\text { Measurement }\end{array}$ & Mean & Median & Range & $\begin{array}{c}\text { Interquartile } \\
\text { Range (IQR) }\end{array}$ \\
\hline At base & 64.75 & 63.5 & 10 & 5.5 \\
\hline At midpoint & 59.5 & 58 & 10 & 5 \\
\hline At the tip & 55.5 & 54 & 10 & 5 \\
\hline \multicolumn{6}{|c|}{ Table 6. Analysis of the Interstyloid Distance } \\
\hline
\end{tabular}

\begin{tabular}{|c|c|c|}
\hline Author & Year of Study & $\begin{array}{c}\text { Incidence } \\
\text { Rate (\%) }\end{array}$ \\
\hline Eagle WW(1) & 1937 & $28 \%$ \\
\hline Winkler S et al(9) & 1981 & $4 \%$ \\
\hline Langlais RP et al(10) & 1986 & $1 \%$ \\
\hline Harmer R(11) & 1988 & $4.7 \%$ \\
\hline Kawai $\mathrm{T}$ et al(12) & 1990 & $8.2 \%$ \\
\hline Bozkir MG et al(13) & 1999 & $4 \%$ \\
\hline Balcioglu HA et al(14) & 2009 & $3.3 \%$ \\
\hline Rathva et al(15) & 2013 & $2 \%$ \\
\hline Rajanigandha et al(16) & 2015 & $4.5 \%$ \\
\hline Jinu Merlin Koshy et al(17) & 2015 & $8.8 \%$ \\
\hline CCDSA Lins et al(18) & 2015 & $38.57 \%$ \\
\hline Present Study & 2017 & $12.1 \%$ \\
\hline \multicolumn{3}{|c|}{$\begin{array}{c}\text { Table 7. Comparison of Various Studies on Incidence of } \\
\text { Elongated Styloid Process }\end{array}$} \\
\hline
\end{tabular}




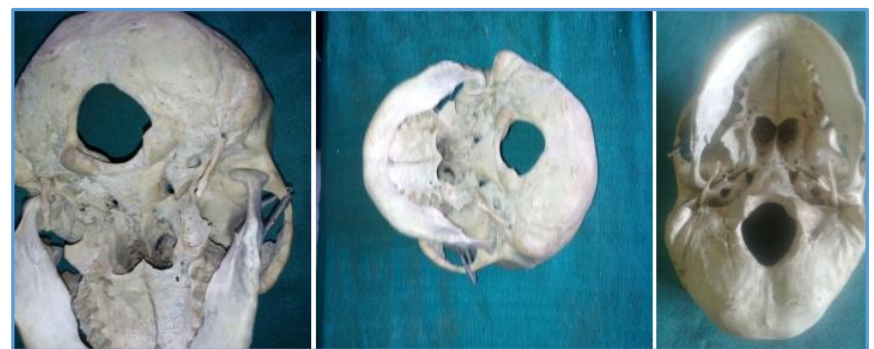

Photographs of Bilaterally Elongated Styloid Process

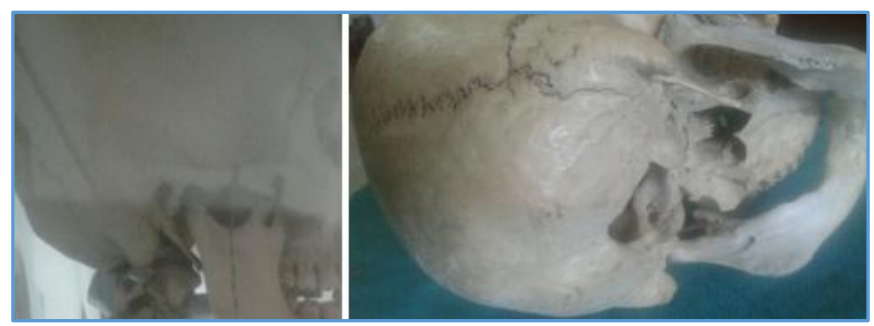

Photographs of Unilaterally Elongated Styloid Process

\section{DISCUSSION}

Review of literature reveals that the length of the styloid process varies considerably in the population. Eagle WW stated that the normal length of the styloid process ranged from $25-30 \mathrm{~mm}$ in normal adults.(19,20) In the present study we found that among the 140 specimens, 123 skulls had styloid process that were within the normal range of $25-30$ $\mathrm{mm}$ as stated by Eagle. The length of the elongated styloid process that we found ranged from $31 \mathrm{~mm}$ to $40 \mathrm{~mm}$. However, there are reports where the elongated styloid process was found to be $47.7 \mathrm{~mm}$ to $73 \mathrm{~mm} .{ }^{(21,22)}$ Styloid process elongation can occur unilaterally or bilaterally in a skull. Also there are authors who claim that elongated styloid process is more common unilaterally.(23) In our study also, we found more numbers of unilaterally elongated styloid process.

The stylohyoid chain extends between the temporal bone and the hyoid bone and is divided into four sections- a) Tympanohyal (forms the base of the styloid process), b) Stylohyal (forms major portion of the styloid process), c) Ceratohyal (forms the stylohyoid ligament), d) Hypohyal (forms the lesser horn of the hyoid bone). The first two sections form the styloid process.(15) The stylohyoid ligament may undergo calcification due to trauma like tonsillectomy.(24)

Awareness about the clinical and radiological presentation of elongated styloid process is important for all health practitioners. An elongated styloid process deviating slightly from its normal direction could impinge the internal or external carotid artery and cause pain during palpation of the artery, because it stimulates the sympathetic nerve plexus accompanying the artery. This fact correlates hypertension in cases with elongated styloid process.(25) An elongated styloid process can trigger a series of symptoms such as dysphagia, ear ache, headache, facial pain, tinnitus, trismus, foreign body sensation in the throat which is termed the Eagle's syndrome. Eagle described the classic syndrome as persistent pain in the pharynx, aggravated by swallowing with the pain frequently referred to the ear on the side of the elongated styloid process. (26)
Differential diagnosis of Eagle's syndrome include unerupted molar tooth, dental prosthesis implantation, disease of the temporomandibular joint, tumours in the oropharynx and laryngopharynx.(27) Eagle's syndrome is most commonly seen in adults and is more common in menopausal females due to hormonal changes.(28)

In this study, we found bilateral elongation of styloid process in $4(2.8 \%)$ cases and unilateral elongation in 13 (9.2\%) cases. Our findings correlates with the findings of Rajanigandha Vadgaonkar et al,(16) who found bilateral elongation of styloid process in $1.8 \%$ and unilateral elongation of styloid process in $2.7 \%$ of their 110 specimens. Our results are also similar to the findings of Jinu Merlin Koshy et al,(17) who reported $2.2 \%$ bilateral and $6.6 \%$ unilateral elongated styloid process in their study.

In the present study, the incidence rate of elongated styloid process was found to be $12.1 \%$ among the population of North-East India. Our findings is similar to that of Kawai T et al $(8.2 \%)$, Harmer R (4.7\%) and Jinu Merlin Koshy et al (8.8\%). $(12,11,17)$

As bilaterally elongated styloid process reduces the interstyloid distance mainly at the level of the tip, it could compress the important structures of the neck giving rise to the symptoms of Eagle's syndrome. However, only symptomatic elongation of styloid process warrants surgical excision.

\section{CONCLUSION}

The elongation of the styloid process is an anatomical variation, which must be taken into account by the clinicians. The morphometric data of the styloid process is important to the dentists, radiologists, neurologists, ENT surgeons and anthropologists. This study is an attempt to contribute to the literature, information regarding the incidence rate of elongated styloid process in this part of India.

\section{REFERENCES}

[1] Eagle WW. Elongated styloid process: symptoms and treatment. Archives of Otolaryngology 1958;67(2):172-6.

[2] Steinmann EP. A new light on the pathogenesis of the styloid syndrome. Archives of Otolaryngology 1970;91(2):171-4.

[3] Camarda AJ, Deschamps C, Forest D. I. Stylohyoid chain ossification: a discussion of etiology. Oral surg Oral med Oral pathol 1989;67(5):508-14.

[4] Kaufman SM, Elzay RP, Irish EF. Styloid process variation. Radiologic and clinical study. Arch Otolaryngol 1970;91(5):460-3.

[5] Ilguy D, Ilguy M, Flsekcioglu E, et al. Assessment of the stylohyoid complex with cone beam computed tomography. Iranian journal of Radiology 2013;10(1):21-6.

[6] Feldman VB. Eagle's syndrome: a case of symptomatic calcification of stylohyoid ligament. J Can Chiropr Assoc 2003;47(1):21-7.

[7] Miller DB. Eagle's syndrome and the trauma patient. Significance of an elongated styloid process and/or ossified stylohyoid ligament. Funct Orthod 1997;14(2):30-5. 
[8] Godden DR, Adam S, Woodwards RT. Eagle's syndrome: an unusual cause of clicking jaw. Br Dent J 1999;186(10):489-90.

[9] Winkler S, Sammartino FJ, Sammartino FJ, et al. Stylohyoid syndrome. Report of a case. Oral Surg Oral Med Oral Pathol 1981;51(2):215-7.

[10] Langlais RP, Miles DA, Dis VML. Elongated and mineralized stylohyoid ligament complex: a proposed classification and report of a case of eagle's syndrome. Oral Surg Oral Med Oral Pathol 1986;61(5):527-32.

[11] Harma R. Stylalgia: clinical experience of 52 cases. Acta Otolaryngol 1988;(Suppl 224):149.

[12] Kawai T, Shimozato K, Ochiai S. Elongated styloid process as a cause of difficult intubation. J Oral Maxillofac Surg 1990;48(11):1225-8.

[13] Bozkir MG, Boga H, Dere F. The evaluation of styloid process in panoramic radiographs in edentulous patients. Tr J Med Sci 1999;29:481-5.

[14] Balcioglu HA, Kilic C, Akyol M, et al. Length of the styloid process and anatomical implications for eagle's syndrome. Folia Morphol (Warsz) 2009;68(4):265-70.

[15] Rathva A, Kubavat DM, Nagar SK. Study of styloid process: anatomical variations in length, angulation and distance between the two styloid processes. Int J of Recent Trends in Science \& Technology 2013;8(2):109-12.

[16] Vadgaonkar R, Murlimanju BV, Prabhu LV, et al. Morphological study of styloid process of the temporal bone and its clinical implications. Anat Cell Biol 2015;48(3):195-200.

[17] Koshy JM, Narayan M, Narayanan S, et al. Elongated styloid process: a study. J Pharma Bioallied Sc 2015;7(1):S131-3.
[18] Lins CCDSA, Tavares RMC, Silva CCD. Use of digital panoramic radiographs in the study of styloid process elongation. Anatomy Research International, Article ID 474615 2015;2015:7.

[19] Lima JL, Rocha JF, Riberio ED, et al. Eagle's syndrome: a review of literature. Acta Odontologica Venezolana 2007;45(2):290-3.

[20] Eagle WW. The symptoms, diagnosis and treatment of elongated styloid process. Am Surg 1962;28:1-5.

[21] Murtagh RD, Caracciolo JT, Fernandez G. CT findings associated with eagle's syndrome. AJNR 2001;22(7):1401-2.

[22] Scaf G, Freitas DQ, Loffredo LC. Diagnostic reproducibility of the elongated styloid process. J Appl Oral Sci 2003;11(2):120-4.

[23] Vougiouklakis T. Overview of the ossified stylohyoid ligament based on more than 1200 forensic autopsies. J Clin Forens Med 2006;13(5):268-70.

[24] Ghosh LM, Dubey SP. The syndrome of elongated styloid process. Auris Nasus Larynx 1999;26(2):16975.

[25] Jackson FE. Hemicrania secondary to elongated styloid process the eagle's syndrome. Dis Nerv Syst 1974;35(11):528-31.

[26] Eagle WW. Elongated styloid process: report of two cases. Arch Otolaryngol 1937;25(5):584-7.

[27] Jain D, Chauhan JS, Goel G, et al. Elongated styloid process: an unusual cause of neck pain and difficulty in swallowing. J Orofac pain 2011;25(3):269-71.

[28] Keur JJ, Campbell JP, McCarthy JF, et al. The clinical significance of the elongated styloid process. Oral Surg Oral Med Oral Pathol 1986;61(4):399-404. 